\title{
The Quiet Revolution: The Development of the Exclusive Economic Zone and Implications for Foreign Fishing Access in the Pacific
}

Deborah Cass

Deborah Cass, 'The Quiet Revolution: The Development of the Exclusive Economic Zone and Implications for Foreign Fishing Access in the Pacific' (1987) 16 Melbourne University Law Review 83, 83-102 <http://www5.austlii.edu.au/au/ journals/MelbULawRw/1987/5.html>.

Reproduced with the permission of the Melbourne University Law Review.

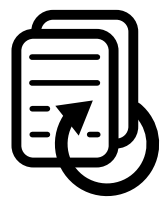





\title{
THE QUIET REVOLUTION: THE DEVELOPMENT OF THE EXCLUSIVE ECONOMIC ZONE AND IMPLICATIONS FOR FOREIGN FISHING ACCESS IN THE PACIFIC
}

\author{
BY DEBORAH CASS*
}

\begin{abstract}
[The exclusive economic zone, established under the 1982 Convention on the Law of the Sea, represents a significant incursion on traditional fishing rights on the high seas and has caused some commentators to view it with suspicion. Under the regime, coastal states have sovereign rights over resources within a 200 mile limit. This article examines the historical development of the zone, rights and responsibilities within it, and its relevance to Australia. It then focuses on the question of how coastal states determine the right of access to the zone of foreign fishing powers. A detailed discussion of the provisions with regard to access follows. The author concludes that the decision to grant access is entirely within the discretion of the coastal state, and that the determination will be made predominantly on the basis of economic considerations. This proposition is then illustrated with examples of the practice of states, including Australia, in the Souih Pacific region.]
\end{abstract}

\section{INTRODUCTION}

Nations have been arguing over fishing rights since Jonah and the whale. Such disputes hardly seem the basis for a revolution. But that is exactly what is happening in the Pacific, with the introduction of the 1982 U.N. Convention on the Law of the Sea. ${ }^{l}$ The once common practice of large nations exploiting the waters of smaller, less sophisticated states is no longer acceptable at international law. Large nations now must pay for the right to fish in someone else's backyard.

This dramatic change has brought with it the fear of a revolution of a more sweeping kind. 'Soviets get new Pacific toehold' was the headline of a front page news report when the Soviets outbid the U.S. for fishing rights in Kiribati. ${ }^{2}$ Fishing rights have suddenly become the battleground for global ideological conflict.

The vehicle of this change is a new doctrine of international law - the exclusive economic zone (E.E.Z.). Ostensibly it is an innocuous enough doctrine which aims to conserve and manage the living resources within its area. However, these objectives gain in significance because of the enormous area and fish stocks covered by the Zones. With over $35 \%$ of ocean and $75-80 \%$ of stock within the E.E.Z. jurisdiction, ${ }^{3}$ the new doctrine is vital to the world economy.

As far as international law is concerned, the evolution of the concept of the exclusive economic zone is important for two main reasons. First, it represents a significant incursion on traditional notions of freedom of the high seas. Secondly, its evolution is an excellent example of the complex interplay of forces which affect the development of a new rule at international law.

* Arts/Law student, University of Melbourne. Research Assistant to Commission of Inquiry into Rehabilitation of the Worked Out Phosphate Land in Nauru. The author wishes to thank Dr Gillian Triggs for her support, encouragement and advice.

I U.N. Doc. A/CONF. 62/I22 (1982) - hereafter cited as U.N.C.L.O.S. III

2 Age (Melbourne) I April 1986.

3 Belsky, M.H., 'Management of Large Marine Ecosystems: Developing a New Rule of Customary International Law' (1985)22 San Diego Law Review 733, 759. 
This paper will attempt to illustrate these reasons by focussing on the most crucial aspect of the exclusive economic zone - the right of the third parties to have access to the living resources of the E.E.Z. A number of problems have arisen in this area, including the interpretation of key clauses such as total allowable catch. Another issue concerns the type of factors for consideration by the coastal state in granting access. The paper will conclude that the rights of the coastal state to determine the right of third parties to have access are completely discretionary. This causes some legal commentators to view the new doctrine with suspicion. Yet, economic considerations will be shown to be the determining factor in calculations between coastal states and distant water fishing nations in the South West Pacific region.

At the outset it should be noted that the question of access is extremely contentious in both legal and political terms. The advance on customary international law in the area of access has led one legal commentator to remark that the United Nations Law of the Sea Convention (1982) represents the 'triumph of individualism over collectivism', ${ }^{4}$ implying that the individual coastal state will benefit at the expense of the international community. Similarly, Juda describes the E.E.Z. as representing the danger of 'creeping jurisdiction', because E.E.Z. claims may become the precursors of claims to extend the territorial sea. ${ }^{5}$ Political responses, particularly from the United States, have also been forceful.

These wamings are particularly relevant to Australia which is currently taking a spectator's role in the negotiations between the United States and the South Pacific nations over the question of U.S. access to tuna stocks in the Pacific. The Soviet Union has just purchased access to fishing rights in Kiribati for $\$ 2.4$ million for the next 12 months. ${ }^{6}$ For these reasons, it is important that Australia understands the impact of the development of the E.E.Z. on the region.

For ease of exposition this paper will be divided into two parts: Part $A$, the exclusive economic zone, and Part B, fishing rights focussing on access in particular. The first part will look at the historical background to the E.E.Z., the rights and responsibilities of nations generally within the zone, and the position of Australia.

The second part will be divided into four sections and will detail the general articles of U.N.C.L.O.S. III which regulate fishing rights in the zone, and then focus on the particular problem of access. Following these two sections will be a discussion of the relationship between state practice in the area of access and the evolution of customary international law.

The final part of the second section will take up the discussion with particular application to the South West Pacific region. It will look at state practice evidenced by the incorporation of the U.N.C. L.O.S. III provisions in domestic legislation and in multilateral agreements, and conclude with a comparison of the South West Pacific experience with Australia's fishing zone.

4 O'Connell, D. P., The International Law of the Sea. Vol. 1 (1982) 552.

5 Juda, L., 'The E.E.Z.: Compatibility of National Claims and the U.N. Convention on the Law of the Sea' (1986)16 Ocean Development and International Law 44.

6 Doulman, D. J., Round Six of the Pacific Tuna Treaty Talks, Pacific Islands Development Program, unpublished, 5. 
It should be noted that primary material in this latter part of the paper is scarce because the island states concerned do not possess the kind of bureaucracies to which we are accustomed to produce the data required. It should not be assumed therefore that this paper is conclusive, rather on the limited information available it is hoped that it will raise some of the problems of intepretation and look at how States in the region have dealt with these issues.

\section{A. THE EXCLUSIVE ECONOMIC ZONE}

\section{Historical background}

Until recently, international law assumed international waters were res nullius: totally free and belonging to any nation. Nation states which had the technology and capital to support lengthy fishing expeditions were free to exploit the resources of seas adjacent to other States. ${ }^{7}$

This freedom initially existed because territorial boundaries extended no further than the low water mark of the physical terrain. However, by the mid nineteenth century a new rule had evolved: the notion of the three mile territorial sea. This rule had its antecedents in the concept of the canon shot limit, which held that a nation's sovereignty extended as far as it could protect itself - hence the canon shot measure. The existence of a new rule was confirmed by the Anglo-French Fishing Convention of 1839 which recognised that the three mile area of sea beyond the low water mark formed part of the territory of the State, although traditional interests still thrived beyond.

It was not until the end of the 19th century that the emphasis began to shift from the economic merits of maintaining traditional rights to the conservation of stocks by the coastal state. ${ }^{8}$ It was part of an overall movement to re-evaluate outmoded colonial values which had condoned the rights of distant water fishing nations to exploit the resources of other states. But international law still lagged behind concern over exhausting resources of the seas.

The process of recognizing adjacent state sovereignty received a major fillip in 1951. In that year Chile declared national sovereignty over its continental shelf and areas adjacent to its coastline to the extent necessary to protect its natural resources up to a 200 nautical mile limit. The scientific basis of the Chilean claim was clearly demonstrable, a fact which was not always present in later claims. ${ }^{9}$

The next significant step towards recognizing coastal state sovereignty beyond the territorial sea occurred at the 1958 United Nations Conference on the Law of the Sea (U.N.C.L.O.S. I) with the introduction of the continental shelf regime. While the Continental Shelf Convention did not provide the coastal state with any rights in the water column above the shelf area it did create the significant precedent of extending state sovereignty beyond contemporary limits.

7 According to Beslky, op. cit. 744 , the history of the law of the sea has been to strike a balance between a broad interpretation of the freedom of the seas and a narrower interpretation of the notion of adjacent state sovereignty. The result had been to tip the balance almost completely toward the view that freedom of the high seas was immutable and included the 'right' to overfish.

8 O'Connell, op. cit. 524.

9 The rationalization was the peculiar geography of the area and the vicissitudes of the Humboldt current. 
A number of Latin American claims later followed the 1951 Declaration of Santiago, including the Montevideo Declaration of the Law of the Sea in $1970^{10}$ and the Declaration of Santa Domingo on the Patrimonial Sea in 1972. They also had the effect of extending coastal state control over adjacent waters. The Latin American claims marked the beginning of the concern that the delimitation of high seas was at risk of being encroached upon. The United States repeatedly protested against these assertions of jurisdiction. ${ }^{\text {II }}$

The next step occurred with the landmark Fisheries Jurisdiction Case (U.K. v. Iceland) in $1974 .{ }^{12}$ The background to the case was a longstanding dispute between the two countries over the rights of British trawlers to fish in Icelandic waters. In 1951 Iceland unilaterally declared a 12 mile territorial sea which resulted in concerted protest from the United Kingdom. In 1961, through an exchange of notes, the U.K. agreed to recognize Iceland's zone on the condition that the phasing out of Britain's fishing interests be gradual and that notice be given if the zone was to be further extended. Iceland responded in 1971 by extending the zone to 50 miles. The U.K. protested again. Iceland ignored the protests and in 1972 legislated to enforce the new zone. The U.K. challenged the validity of Iceland's legislation in the International Court of Justice.

The result was mixed. The Court found that two trends in international law had emerged since 1958: one, the acceptance of a 12 mile territorial sea and two, the concept that the coastal state has preferential rights in adjacent waters particularly if the coastal state is dependent on these waters, but that these rights were not to be exercised to the exclusion of historic rights. Iceland's 50 mile fishing zone was held to be invalid, but in the course of the judgment the Court recognized the concept of coastal states possessing 'preferential rights' in adjacent waters. The Court's recommendation was that the parties return to the negotiating table to sort out an equitable solution.

The case is significant in terms of the development of the E.E.Z. concept because it was the first time that the Court had recognized that coastal states had the right to exercise some form of control (although only preferential) over the fishing resources of the area adjacent to its territorial sea. It was also significant that this decision was made despite the failure of the second Law of the Sea Conference in 1960 to agree to an extension of the territorial sea to the 12 mile limit.

By the time of the Third Law of the Sea Conference in 1982 most states had declared an adjacent fishery zone, although the form and content of that zone varied greatly between states.

At U.N.C.L.O.S. III a number of different solutions were proposed. The Latin American states favoured seabed and fisheries jurisdiction combined to 200

10 The Montevideo Declaration does list amongst its criteria the 'right to establish the limits of maritime sovereignty and jurisdiction . . .' in its 200 mile zone. The use of the word 'sovereignty' would tend to support O'Connell's statement. In contrast the Santa Domingo Declaration talks in terms only of 'sovereign rights'. In any event both claims were part of a general movement towards the recognition of the coastal state's rights over the resources in the waters superjacent to its continental shelf.

11 O'Connell, op. cit. 557 expresses some reservations about the scientific basis of these later claims and concludes that 'they were in practice indistinguishable from territorial waters claims'.

12 I.C.J. Reports 1974, 3. 
miles; the African states sought to stress the 'economic' nature of the zone; Australia and New Zealand advocated a limited fisheries management zone and the distant water fishing nations (D.W.F.N.s), such as the United States and Japan, argued that as they were best equipped to ensure that the maximum yield was taken, they should be free to continue fishing in the traditional manner. ${ }^{13}$ The actual text of the provisions resembles the position put by the developing states. The cornerstone article (article 56) provides that the coastal state in the E.E.Z. has 'sovereign rights for the purpose of exploring and exploiting, conserving and managing the natural resources . . . of the waters superjacent to the sea-bed'. ${ }^{14}$

One final aspect of interest to the history of the E.E.Z. is the innovative method of decision-making used to approve U.N.C.L.O.S. III. No votes were taken on separate provisions, instead the Convention was treated as a 'package' with states compromising on one provision in order to get another one accepted. By using this method of consensus decision-making it was hoped to speed up the ratification process and to ensure the immediate acceptance of U.N.C.L.O.S. III as customary international law. However a number of writers are sceptical of the effectiveness of this process. Harris remarks that 'it must be borne in mind that the consensus favouring the inclusion of a particular rule as a part of the overall package may mask opposition to the rule taken by itself.' ${ }^{15}$ On the other hand it could be argued that, given the painstaking process of negotiation and the time it took to negotiate (nine years), the third Law of the Sea Convention is the most representative piece of legislation that the international community has produced.

What is certain is that the E.E.Z. provisions of U.N.C.L.O.S. III did reflect state practice. By 1982 a majority of states had already declared an adjacent zone over which they had some rights over the living resources. To this extent the provisions were merely declaratory of existing law, although there are particular aspects of the E.E.Z. regime which arguably represent an extension on customary international law (the provisions with regard to highly migratory species beyond the E.E.Z. for instance ${ }^{16}$ ). In this respect they are a mixture of what Harris calls 'codification and progressive development'. ${ }^{17}$

Whether or not U.N.C.L.O.S. III does come into force - and at this stage this is arguably doubtful with only 28 ratifications of the 60 required - the E.E.Z. has acquired sufficient status to have become part of international law. What this actually means in terms of rights and obligations of nations will be discussed generally in the following section. ${ }^{18}$

13 O'Connell, op. cit. ch. 15.

14 A number of other relevant changes were also made in 1982 . They included the extension of the territorial sea to 12 miles, increased rights for archipelagic and land-locked states, improved marine pollution control, changes to the continental shelf regime, the development of a regulatory mechanism for deep sea-bed mining, the establishment of an International L.O.S. Tribunal in Hamburg and the introduction of compulsory judicial arbitration and settlement of most disputes.

15 Harris, D. J., Cases and Materials on International Law (3rd ed. 1983) 286.

16 See Infra.

17 Harris, op cit. 284.

18 Even if the Convention is not ratified by all signatories, there is an obligation for nonsignatories not to defeat or frustrate the purpose of the treaty. Art. 18 of the Viemna Convention on the Law of Treaties states that if a state has signed the treaty or has expressed its consent to be bound by the treaty pending entry into force of the treaty, 'a State is obliged to refrain from acts which would defeat the object and purpose of a treaty.' 


\section{Rights and Responsibilities in the E.E.Z.}

The main article of the E.E.Z. provisions is article 56 which provides that the coastal state has 'sovereign rights for the purpose of exploring and exploiting, conserving and managing the natural resources, whether living or non-living, of the waters superjacent to the seabed and of the sea-bed and its subsoil . . .'

The Convention continues to list the breadth of the zone (article 57), the rights and duties of other states (article 58), and the basis for the resolution of conflicts (article 59). It then further elaborates on the requirements of article 56. Articles 61 and 62 deal with conservation and utilization of the living resources respectively, article 63 looks at the problem of shared stocks and article 64 focuses on highly migratory species. The rights of land-locked and geographically disadvantaged states are also dealt with in articles 69 and 70 .

There are a number of points to note about these general articles. First, article 56 accords the coastal state 'sovereign rights' and not sovereignty. This wording was deliberate. It will be recalled that prior to U.N.C.L.O.S. III many states had already declared adjacent zones of control. Juda commented in an article on the compatibility of national claims and the Convention that many states had (possibly unwittingly) claimed 'sovereignty' over their Zones. The Convention therefore sets a limit on coastal states' rights while still according them control sufficient to carry out the duties set out in the provisions. In O'Connell's view, the term 'sovereign rights' underscores the limited authority of the coastal state. ${ }^{19}$

The E.E.Z. is therefore a transitional zone between the freedom of the high seas and the sovereignty of the territorial $\operatorname{sea}^{20}$ and has been labelled a zone sui generis by a number of writers.

The second area of interpretative difficulty occurs in the provisions dealing with the general rights and duties of other states. Paragraph 2 of article 56 says that the coastal state 'shall have due regard to the rights and duties of other states'. It is not at all clear what 'due regard' means in this context. Does it mean that the coastal state must take into account the interests of other states or is it just a mechanism to encourage discussion between the parties in the event of a conflict? It is likely to be the latter, given the wide-ranging scope of coastal state authority defined by article 56 .

The authority of the coastal state is subject to some limits. The freedoms of navigation and overflight and the laying of submarine cables and pipelines are all recognized by article 58 . (Juda's survey of legislation found that less than half explicitly recognized these freedoms.) Other provisions dealing with access do not limit coastal authority as such, but they do place an obligation upon the coastal state at least to consider the allocation of any fishing surplus. These will be discussed later.

\footnotetext{
19 Although it should also be pointed out that the language of art. 56 is not permissive - the coastal state 'has' certain rights, not 'may claim'. This usage stresses the mandatory element of their control.

20 Juda, op. cit. 2.
} 
The third area of potential difficulty is article 59 dealing with the resolution of conflicts regarding the attribution of rights and jurisdiction in the exclusive economic zone. It says that "the conflict should be resolved on the basis of equity and in respective importance of the interests involved to the parties as well as to the international community as a whole'. This appears to be one of those provisions to which Harris referred to earlier in which the attempt to achieve consensus has masked opposition below. The provision tries to strike a balance which is commendable but perhaps unrealistic. The interests of the parties may not always be compatible with the interests of the international community, and furthermore it may be that neither of these is necessarily reconcilable with 'equity'. ${ }^{21}$

The significance of these ambiguities is increased by the fact that rights and jurisdictional conflicts are specifically exempted from the generally compulsory dispute resolution procedures of article $297(3) .{ }^{22}$ In other words the discretion of coastal states to decide whether or not to allocate their surplus is not open to dispute except according to the limited procedures of article 59.

There is possibly one other area of uncertainty and that is in the relationship between the E.E.Z. and the continental shelf. As already mentioned the rights attached to the sea-bed and subsoil must be exercised in accordance with Part VI dealing with the continental shelf. O'Connell believes that this dual legislative approach hides a basic contradiction in the Convention whereby access to mineral resources is exclusive under Part VI, but access to fishing resources is only preferential under Part V. The meaning of 'exclusive' is thus qualified in this context. O'Connell continues,

There is . . . a fundamental legal instability in this doctrine which can only be productive of grave difficulties of interpretation. ${ }^{23}$

O'Connell does not elaborate on this point. However, one theme of this paper will be to show on the basis of this research and limited primary sources that the coastal state has total discretion with regard to access. It follows that while the zone may not be 'exclusive', it is certainly much more than 'preferential'. 'Preferential' implies that other factors may direct the coastal state decision with regard to access, but as has already been noted with regard to dispute resolution alone, this is not the case. Third parties have only a limited right to challenge any decision. Thus the legal instability which O'Connell rightly perceived may have turned out to be more apparent than real. It appears that while there are certain responsibilities put on coastal states to consider the interests of third parties, once that consideration has been made the coastal state may decide in its own best interests. In practice then there may be little difference between this authority and that exercised by the coastal state with regard to its continental shelf.

21 Does this provision refer to equity as a body of law or does it merely foresee the use of 'equitable' solutions? As the provision is quite explicit it appears that it requires reference to the particular rules of equity.

22 This article provides that disputes over coastal state authority are not subject to the general dispute resolution procedures. The only exceptions are the arbitrary acts of the coastal state with regard to determining its total catch or the consideration of allocation of its surplus. And even though these exceptions can be arbitrated upon the decisions are not binding.

23 O'Connell, op. cit. 553. 


\section{Position of Australia generally}

The countries which benefit most from the campaign led by the developing countries are the developed countries, ${ }^{24}$ including Australia, New Zealand and the United States, which have the largest 200 mile zones.

Another factor which underscores the benefits of the E.E.Z. campaign for Australia is that it is not a long distance fishing industry. ${ }^{25}$ Therefore Australia had nothing to lose and everything to gain by supporting the proposal at U.N.C.L.O.S. III.

Prior to the Convention in 1978, the Department of Foreign Affairs was called upon to produce a paper assessing the situation and put forward a favoured position. At the time that the 'L.O.S. Australia Maritime Boundaries' Report ${ }^{26}$ was produced Australia claimed a 3 mile territorial sea and a 12 mile continguous zone. The package eventually proposed by Australia called for a zone where the coastal state had exclusive responsibility for the maintenance and conservation of fishing resources, but also had an obligation to allow others to take the surplus on terms and conditions defined by the coastal state. A position very similar to this was finally accepted by the Conference.

A reflection of this position can be seen in the legislation declaring Australia's fishing zone (A.F.Z.). There are no criteria restraining the government's choices with regard to access except that of 'optimum utilization' which, as shall be seen later, is hardly an onerous requirement. In contrast the legislation of Fiji does include the criteria of "the benefit that other nations provide ... in terms of research, identification of stocks, and the conservation and management of fishing resources'. ${ }^{27}$

Australia played a kind of mediating role in negotiations at U.N.C.L.O.S. III. This role was a reflection of Australia's political role in the region - as both a close associate of the island states in the Pacific and an ally of the United States. For instance, Australia's compromise proposal on highly migratory species (H.M.S.) - which was eventually rejected - gave the coastal state special rights with regard to H.M.S. but these rights were to be regulated by an international organization. ${ }^{28}$

Another Australian compromise, which was successful, was one concerning the marine environment. It allowed coastal states to unilaterally legislate on pollution controls, as long as that legislation was 'reasonable'. ${ }^{29}$ Obviously Australia's interest in the Barrier Reef was relevant to this position.

Having now considered the background to the evolution of the E.E.Z. the general rights envisaged by the Convention and the role played by Australia at the Conference, we are now in a position to review the particular problem of access.

\footnotetext{
24 lbid. 557.

25 Phillips, J. C., 'The Economic Resources Zone and the Southwest Pacific' (1982) 16 International Lawyer $265,266$.

26 Greig, D. W., (ed.) Australia Year Book of International Law 315 ff.

27 Marine Spaces Act 1977 (Fiji) s. 11; Phillips, op. cit. 269.

28 Phillips, op. cit. 270.

29 lbid. 272.
} 


\section{B. FISHING RIGHTS: ACCESS}

\section{General responsibility}

It will be recalled that the coastal state has sovereign rights for the purpose of exploring, exploiting, conserving and managing the natural resources of the waters superjacent to the sea-bed under article 56. It must also have due regard to the interests of other states in determining its rights and duties. Thus the question of access is firstly determinable by the coastal state limited only by regard for other states' interests.

The process of how this determination will actually occur is outlined in the subsequent provisions, which deal with conservation, utilization, shared stocks, highly migratory species, and land-locked and geographically disadvantaged states (L.L.G.D.S.) ${ }^{30}$

The following section will discuss the relevant provisions dealing with access by attempting to answer a number of questions: it will look at the actual wording of the provision, discuss any limits or ambiguities, define any legal problems with the provision, and discuss how these have been interpreted.

\section{Fishing provisions}

\section{(a) Total allowable catch}

The central feature of the conservation and management requirement is that under article 61 the coastal state shall determine the allowable catch of the living resources in its E.E.Z. It should be done by taking into account the 'best scientific evidence' to ensure that the living resources are not 'endangered by overexploitation'.

The determination of the allowable catch is a discretionary decision, not to the extent as to whether it can be made, but as to how it can be made. While the Convention goes to great lengths to define the process, it also contains many qualifications which allow the coastal state to make the determination at its own discretion.

The first of these qualifications can be seen in paragraph 2 of article 61 which requires the coastal state to use the 'best scientific evidence available to it'. The problems here are twofold. First, 'best' implies that the coastal state is not required to find the most accurate scientific data but only the best that it can manage. This impression is reinforced by the latter part of the phrase, 'available to it,' which again suggests that the coastal state may not have a positive duty to seek out the data. ${ }^{31}$

30 Burke, W.T., 'The Law of the Sea Conventions Provisions on Conditions of Access to Fisheries Subject to National Jurisdiction' (1984) 63 Oregon Law Review 73, 77 outlines this process as comprising five stages: a) determining the total allowable catch b) calculating the restrictions on harvesting capacity c) making a decision as to how much the coastal state can harvest d) deciding what other nations may have access to harvesting and on what terms and e) negotiating arrangements on the basis of these decisions. This is a convenient structure in which to consider the issues, but it is by no means conclusive.

31 However, the lack of compulsion in this article is to a large extent alleviated by the requirement in para. 5 to contribute and exchange any relevant information through international organizations. 
The maintenance or restoration of the maximum sustainable yield (M.S.Y.) is also open to interpretation. The Convention provides that this is to be ascertained 'as qualified by relevant environmental and economic factors' and then goes on to list a number of factors. The inclusion of the broad delineations 'environmental and economic' suggest that the coastal state may use any number of references to qualify its determination of the M.S.Y. This interpretation is supported by the generous range of factors which are listed subsequently. They are 'the economic needs of coastal fishing communities and special requirements of developing States, and taking into account fishing patterns, the interdependence of stocks'. Thus if the particular fishing community is entirely dependent on fishing for its livelihood, the coastal state may adjust its M.S.Y. accordingly. The implication which can be drawn from the language of the treaty is therefore significant that M.S.Y. is, to an extent, a discretionary measure. ${ }^{32}$

\section{(b) Optimum Utilization}

Article 62 forms the basis of the access decision following on from the determination in article 61 . It provides that the coastal state should 'promote the objective of optimum utilization'. The coastal state should firstly determine its own harvesting capacity. Where its capacity does not exceed the allowable catch it should give other states access to its surplus, having regard to the land-locked and developing states of articles 69 and 70 and certain other criteria of assessment in paragraph 4.

The wording of the first paragraph again indicates the discretionary nature of the obligation on coastal states. It is required only to 'promote' the 'objective' of optimum utilization; there is no compulsion upon the coastal state to achieve a quantifiable standard - this is reflected in the use of the word 'optimum' rather than 'maximum'.

\section{(c) Harvesting capacity}

The concept of harvesting capacity is critical to the equation and yet is also loosely defined. The decision to allocate to other nations is taken by subtracting the coastal states' harvesting capacity from the allowable catch (article 62(2)). Yet if, as Burke notes, the harvesting capacity is dependent on the allowable catch, and, this can be decided by considering whether the coastal states' interests are best served by determining the allowable catch at a level equal to or less than its harvesting capacity, the requirement in article 62(2) places no 'meaningful obligation' 33 upon the coastal states. In practice this will mean that the coastal

32 The effects on associated and dependent species by harvesting further broadens the equation the coastal state must make in order to determine the allowable catch. This widening of responsibility is one which is welcomed by some writers (e.g. Belsky, op. cit.), but will bring with it its own attendant problems. It means that the coastal state must also now have the capacity to research the effects of its actions on the eco-system of which it is a part. This facility will not be available to many of the smaller developing states and is therefore probably not an enforceable obligation.

33 Burke, op. cit. 90 . 
state has the authority to make a choice with regard to harvesting capacity that suits its own best interests. ${ }^{34}$

\section{(d) Dispute settlement}

Under article 297, there is no obligation upon the coastal state to submit to compulsory dispute settlement procedures on an issue arising out of the exercise of its sovereign rights to fisheries. Thus a coastal state's refusal to set an allowable catch or harvesting capacity, which would result in the allocation of its surplus, cannot be challenged. Only if the decision is 'arbitrary' can it be pursued through compulsory 'conciliation', but even this is not binding. Therefore the exclusion of this factor from the dispute procedure leads to the conclusion that 'C.L.O.S. contains virtually no restriction on coastal state authority to forbid access to foreign fishing'. 35

\section{(e) Access}

The actual determination of access is to be made according to the last 3 paragraphs of article 62(2). On the basis of the above mentioned calculation the surplus will be allocated, by agreement, paying due regard to the interests of L.L.G.D.S., and taking into account certain other criteria.

This is not to say that the coastal state will necessarily refuse foreign fishing powers the right of access to their surplus. The opposite is often true. Most coastal states will be more than willing to facilitate access to their Zones because they can charge considerable fees for this right. (There is no restriction on licensing fees in article 62(4)(a)). The economic gains will therefore usually mean that the coastal state will allocate. But under the Convention the terms and conditions of that access are now in the sphere of coastal state authority. This aspect is what is causing the most practical problems, because it means that any access accorded must be paid for on terms which are to the satisfaction of the coastal state.

\section{(f) Land-locked and geographically disadvantaged states}

Some of the constraints on coastal state authority to allocate its surplus are listed in articles 69 and 70 which deal with the rights of land-locked and geographically disadvantaged states respectively. The provisions give the L.L.G.D.S. the right to participate in an 'appropriate part of the surplus' on an 'equitable basis'. While this does give them some right of access, it is limited. Again the words 'appropriate' and 'equitable' imply that the discretion lies with the coastal state making the determination.

There are also limits on the rights of L.L.G.D.S. The right to participate must 'take into account the relevant economic and geographical circumstances of all

\footnotetext{
34 One other minor problem with the concept of harvesting capacity being determinative is the fact that the coastal state could feasibly increase its own harvesting capacity by authorizing foreign vessels to fish under its flag. This would preclude other states legitimately exercising their rights to access under the Convention.

35 Burke, op. cit. 91 .
} 
the states concerned' and it must be 'in conformity with the . . . provisions of article 61 and 62'. This means that the coastal state's 'circumstances' may override the other state's claim.

Furthermore the obligation is limited to one merely of 'co-operation' to achieve an 'equitable arrangement' (articles 69(3) and 70(4)). It appears that there is a duty upon the coastal state, but the use of these terms indicates that it is not an onerous one ${ }^{36}$ Once the coastal state has given consideration to its duty by engaging in negotiations with the L.L.G.D.S. its duty will be fulfilled ${ }^{37}$

Finally, it should be noted here that developed L.L.G.D.S. are restricted to participating in the surplus of another developed state.

Overall, the provisions of articles 69 and 70 are a constraint on coastal state discretion as to access, but this constraint is limited. The author agrees with Burke's view that these articles 'give the L.L.G.D.S or developing L.L.G.D.S. a claim to secure access to the surplus. However, realization of this claim requires negotiating with the coastal state, each bilateral, subregional, and regional agreement, on terms and conditions satisfactory to the coastal state. ${ }^{, 38}$ In this respect the duty upon the coastal state with regard to L.L.G.D.S. is not significantly different to its duty to other states.

\section{(g) Highly migratory species}

Highly migratory species are singled out by the Convention because they pose a particular problem of conservation and management. The issue concerns who has responsibility for stocks which do not stay within the same area during their lifetime. The stock include tuna, which has presented the most problems for the Pacific region. Article 61 places an obligation on all states whose nationals fish H.M.S. to co-operate to ensure that both conservation and optimum utilization of the species occurs.

There is considerable disagreement as to the meaning of this article. Does it override the earlier provisions which give coastal states exclusive authority, or is it an additional obligation to co-operate which does not take away from their sovereign rights under article 56 ? The United States believes that the inclusion of a separate article means that H.M.S. do not come under general coastal state authority and has legislated to give effect to this view. The Fishery Conservation and Management Act of $1976^{39}$ proclaims a fishing zone of 200 miles which does not include jurisdiction over tuna and provides that the U.S. will embargo any state which prevents U.S. vessels fishing for H.M.S. in their zone. This provision was applied when the Solomon Islands confiscated the U.S. tuna boat, the Jeanette Diana, in 1984. This area of the Convention is the main obstacle to U.S. acceptance of the E.E.Z. as outlined in U.N.C.L.O.S. III. ${ }^{40}$

36 Burke, op. cit. 95-10I discusses at length what constitutes co-operation in this context and what consequences would flow from a failure to co-operate.

37 Additionally, a breakdown in communication will not constitute a failure to co-operate to the extent that the coastal state has not fulfilled its duty.

38 Burke, op. cit. 100.

39 Pub. Law 94-265, 94th Cong., ss 101, 102, 103, 201 (c).

40 The U.S. has been unwilling to recognize the E.E.Z. in other contexts. For instance, when negotiating the South Pacific Regional Environmental Treaty, the U.S. refused to discuss dumping restrictions unless the area was defined as a general region rather than the E.E.Z.s of coastal states. 
The U.S. position is rejected by most writers on the subject and all other D.W.F.N.s. Australia has stated that the U.S. juridical position is 'inconsistent with international law'. ${ }^{41}$ There is nothing in the wording of the article which suggests paramountcy over the earlier provisions.

It would also be against the intention of the Convention to vary coastal state general sovereignty with regard to H.M.S. when the aim was to give coastal state authority over all stocks within its E.E.Z. All this provision does is to require the coastal state to exercise this control by means of a particular co-operative process established in article $64 .{ }^{42}$

The only area of potential difficulty is whether or not the coastal state's authority over H.M.S. extends beyond the E.E.Z. If it does then it represents a significant advance in customary international law in broadening coastal state control into the high seas. It appears that in order to discharge its obligation to conserve and manage these stock, the coastal state would have to exercise its authority within the high seas beyond the E.E.Z.

\section{(h) Fishing in the high seas}

Although article 64 places an obligation upon D.W.F.N.s to consider the effects on coastal states of H.M.S. fishing in the high seas, the coastal states do not possess any enforcement authority beyond the limits of the E.E.Z. Likewise there is no authority to take into account high seas stocks in determining the total allowable catch.

On the other hand if, as Belsky argues, the E.E.Z. regime provides an opportunity for states to participate in total eco-system management, high seas stocks may be taken into account. The requirement in article 61(4) to take account of the effects of fishing on associated or dependent species strengthens Belsky's argument.

\section{Access assessed}

A detailed examination of the provisions relating to access therefore reveals that the decision to allocate surplus to third parties rests almost entirely within the domain of coastal state authority. This is because the determinative factors which go toward affecting the decision are all within the control of the coastal state. Allowable catch, harvesting capacity and optimum utilization can all be determined according to the best interests of the coastal state. Subsequent criteria to be used to decide which state can have access are also within coastal control. Even states which are singled out for special consideration, like the L.L.G.D.S, only establish a claim to secure access, not a right to do so. Likewise, stock such as H.M.S., although accorded particular notice, still come within the general authority of the coastal state outlined in the major articles.

41 Australian Foreign Affairs Record, Vol. 56, Sept. 1985, 824.

42 The argument against the U.S. position is further reinforced by the repetition of the words 'conservation' and 'optimum utilization', concepts which are only explicable by reference back to the general provisions of arts 61 and 62 . However, given the present inability of the world community in total to agree on the limited regime within the E.E.Z., it is unlikely that enforcement of similar rights will occur beyond the Zone. 
The latter section of this part of the paper will illustrate these conclusions by reference to documentary material in legislation and agreements and by reports of state practice. It will also show that while coastal state authority may be total in theory, in practice it is very rarely exercised to completely exclude all foreign fishing. O'Connell's concern that the Convention marks the 'triumph of individualism over collectivism' ${ }^{43}$ is unfounded in this respect. Likewise is Juda's suspicion of the 'creeping jurisdiction' of the E.E.Z. ${ }^{44}$ In practice, access is usually accorded for foreign fishing vessels. As Burke comments,

CLOS contains virtually no restriction on coastal state authority to forbid access to foreign fishing. For practical legal purposes, the Convention provides no effective remedy even for arbitrary denials of access . . . However, it must also be emphasized that most coastal States will exercise their discretion to find that a surplus exists and that some foreign access is desirable. ${ }^{45}$

However, what the Convention does is to establish a list of criteria and a process on which to make the judgment as to who is entitled to access. In this way it may provide ready-made reasons for refusing access to states. And in turn this authority may enable states to give access to whichever foreign state is prepared to pay the most for that right. For example, the Soviet Union recently acquired fishing rights to the E.E.Z. of Kiribati to the exclusion of the United States, which had traditionally fished the area. The basis of this decision was purely economic. ${ }^{46}$ The United States refused to pay the $\$ 2.4$ million which Kiribati demanded as the value of its stocks. This example accords with Burke's prediction that a 'decision to maximise revenue from a surplus resource is a reasonable one' ${ }^{47} \mathrm{He}$ continues that 'all conceivable interests that might bear on fisheries, including political, military, educational, ecological, cultural, religious or ideological interests' ${ }^{48}$ may be considered in making this determination. The discretion of the coastal state is virtually unlimited.

\section{Evolution of customary international law}

There are two questions to be answered: one, has customary international law evolved in this area, and two, which particular aspects have evolved?

First, it is clear that while U.N.C.L.O.S. III as a whole was a mixture of what Harris calls 'progressive development' and 'codification' ${ }^{49}$ the provisions relating to the E.E.Z. were, in general, merely codifying existing international law. Prior to the Convention, over 95 countries had already claimed management jurisdiction over adjacent Zones.

Furthermore, the Fisheries Jurisdiction case $\left(U . K . v\right.$. Iceland $^{50}$ indicated that customary international law had evolved at least to the point of recognizing preferential rights for coastal states in adjacent waters. This position has been confirmed by the Mexican Foreign Minister Mr Castenada in an address to the

43 O'Connell, op. cit. 552.

44 Juda, op. cit.

45 Burke, op. cit. 91. Author's italics.

46 The Soviet fleet is not permitted to operate within the territorial waters, nor does it have port privileges in Kiribati. Doulman, op. cit. 6.

47 Burke, op. cit. 103.

48 Ibid.

49 Harris, op. cit. 284.

50 I.C.J. Reports $1974,3$. 
U.N. General Assembly, where he stated that customary international law had evolved to the point that "failure of some countries to sign [the Convention] . . . does not mean, that the world can go back to . . . the 1958 Geneva Convention as if nothing has happened'. 51

The particular aspects of the law of the sea which have evolved are less easy to identify. Certainly there is general acceptance of the concept of coastal state authority within a zone. It is also clear that, despite the United State's assertion to the contrary, most writers believe that coastal state authority extends to H.M.S., at least when those stock are within the E.E.Z., and possibly even when they are beyond in the high seas. It has to be pointed out that the United States accepts this position with regard to all other H.M.S. except tuna. One writer comments that:

The purpose of maintaining the U.S. position on jurisdiction is to give the tuna industry some leverage in negotiations . . there is no matter of principle at stake . . . because the United States itself also claims jurisdiction over HMS, [in its own Zone] only for somewhat different species which have, nonetheless, precisely the same management needs. 52

Thus the United States' aim to shape evolving customary international law has not succeeded and H.M.S. are included within the stock over which the coastal state has authority.

However, one area in the Convention which does represent an advance on customary international law regards H.M.S. outside the E.E.Z. In this respect it does appear that the traditional freedom of high seas fishing has been altered to the extent that this right is now subject to a limited form of coastal state control.

The role of state practice in assessing the evolution of customary international law cannot be underestimated. The doctrine of the E.E.Z. has no theoretical antecedents, unlike that of the continental shelf which is based on the concept of local authority over the terrain. ${ }^{53}$ The status of the E.E.Z. therefore depends greatly for its viability upon state practice.

\section{State practice}

\section{(a) Incorporation and interpretation of E.E.Z. provisions in agreements in the South West Pacific region.}

Having considered the effects of the provisions of the Convention in theory, it is now necessary to look at the practical result of their incorporation in agreements relevant to Australia.

First, to return to the question of access, what have been the preconditions for making such agreements? As pointed out earlier, the criteria for assessing access is extremely broad and economic considerations may be the determining factor. For example, the President of Kiribati, Ieremia Tabai, stated that the decision to allow the Soviet Union to fish in Kiribati's E.E.Z. was 'purely economic' ${ }^{54} \mathrm{He}$

51 Lee, R. S., 'The New Law of the Sea and the Pacific Basin' (1983) 12 Ocean Development and International Law Journal 247, 253.

52 Burke, W. T., 'Highly Migratory Species in the New Law of the Sea' (1984)14 Ocean Development and International Law 273, 307.

53 O'Connell, op. cit. 570.

54 Age (Melbourne) 24 July 1985. 
also said that the Kiribati government would only deal with the United States if it was prepared to pay a 'fair price' ${ }^{55}$ Both these comments illustrate the discretion of the coastal state under article 62 .

Many of the provisions of the Convention are embodied in the agreements between South Pacific States to establish the South Pacific Forum Fisheries Agency,(S.P.F.F.A.) and in the arrangements that agency has subsequently negotiated. The S.P.F.F.A. was set up in 1979. Its functions include the harmonization of fishing policies, encouragement of co-operation with D.W.F.N.s, cooperation with regard to surveillance and enforcement, and co-operation in the determination of access. The agency was in existence before the 1982 Convention and has had to adjust its functions since then. ${ }^{56}$

It acts as a negotiating conduit for discussions between coastal states and D.W.F.N.s. At present it is presiding over discussions to establish a multilateral treaty between the United States and Pacific nations on the question of access to tuna stocks in the Pacific. ${ }^{56 a}$ The outcome of these negotiations is not yet known, and yet is extremely important to the evolution of future practice and consequent custom in the Pacific. According to Doulman, a research fellow with the Pacific Islands Development Program, the United States is still unwilling to pay the S.P.F.F.A.'s licensing fee. ${ }^{57}$ It should be noted that the reference to the United States actually refers to the American Tunaboat Association, not the U.S. government, although generally their position has been the same.

Closer to home, Australia has negotiated a number of agreements pursuant to its legislation. The statements of Australian government officials and the language of various agreements aim to implement the Convention's objectives of conservation and management of the natural resources of the region. One such agreement is the Japan/Australia Fisheries Agreement, which is renewed annually through a subsidiary agreement. It ensures the 'close co-operation with regard to the conservation and optimum utilization' of the living resources within Australia's fishing zone.

The criteria which Australia uses to determine access under this agreement is, more often than not, economic. Two illustrations follow. The first can be seen in a statement to the Parliament by Senator Grimes in October 1984. He said:

\footnotetext{
... in response to earlier concerns by game fishing interests, Japanese longliners have already been excluded from areas off the east coast where direct competition with Australian fishermen was evident. ${ }^{58}$
}

In September of the same year the Minister for Primary Industry, Mr John Kerin, announced a new agreement with Korea for squid jigging within the A.F.Z. He said that Korean vessels would 'not be permitted to fish in any areas where

55 Age (Melbourne) 11 April 1986.

56 Carroz comments that this 'Institutional adjustment' has not been given sufficient consideration. He believes that now that conservation and management regimes are enforceable under the Convention, the role of institutions have, to an extent, been superseded, although in the case of the S.P.F.F.A. this is not the case. See Carroz, J. E., 'Institutional Aspects of Fishery Management Under the New Regime of Oceans' (1984)21 San Diego Law Review 513.

56a See postscript.

57 Doulman, op. cit. 5. See p. 9 for the American Tunaboat Association's 'special case'.

58 Australian Foreign Affairs Record, Vol. 55, Oct. 1984, No. 10, 1117. 
interference with Australian fishermen would occur'. ${ }^{59}$ Both these statements would come under article 62(3) which allows 'the significance of the living resources of the area to the economy of the coastal State concerned' to be taken into account in granting access.

However, as indicated earlier, 'other national interests' (article 62(3)) is extremely broad, and, in the case of Australia, has included the refusal of foreign states to co-operate with local catch limits. The Minister for Primary Industry was prepared to ban access when stocks were threatened. In October 1984 he stated that:

. . under a new agreement Japan tuna vessels would not be able to operate in the A.F.Z. where they could take Southern Bluefin Tuna (S.B.T.) because they would not accept controls Australia put on its own fishermen. ${ }^{60}$

However, the fact that broad discretion has been given to the coastal state and a certain decision has been made excluding another state from participating in its surplus, does not mean that the decision cannot be reviewed. Once the Japanese industry was prepared to limit its global catch, new tuna agreements were negotiated. ${ }^{61}$ The role of the Convention in this example was to provide the Australian government with the authority necessary to enforce certain obligations on a foreign fishing power in order to conserve its depleted stock.

Thus the wording of the various agreements is similar to that in the Convention. It repeats the requirements of conservation, optimum utilization, allowable catch and the determination of allocation of surplus. Additionally, the Pacific agreements also specify the management of tuna stocks pursuant to article 64 of the Convention.

\section{(b) Incorporation of the E.E.Z provisions in Domestic Legislation}

The incorporation of the E.E.Z. objectives in legislation does not always reflect the language of the Convention. Juda found that much domestic legislation does not mention optimum utilization or the right of third party access to the Zones. ${ }^{62}$

Even when domestic legislation does refer to foreign access, only a small number provide any explicit indicia for determining such access. ${ }^{63}$ Australia leaves the decision entirely up to governmental discretion. New Zealand refers to the benefits given to the industry by the foreign fishing state in terms of the identification of stocks.

\section{(c) The Pacific region compared with Australia}

The former Minister for Foreign Affairs, Mr Andrew Peacock, distinguished Australia's Zone in October 1979 as a fishing zone. While there is little difference in practical effect, it is worth noting why this distinction was made as it may also explain why Australia has had little of the difficulties experienced by other developed nations.

\footnotetext{
59 Australian Foreign Affairs Record Vol. 55, Sept. 1984, 1006.

60 Australian Foreign Affairs Record Vol. 55, No. 10, Oct. 1984., 1132.

61 Australian Foreign Affairs Record Vol. 55, No. 9, Sept. 1984, 1006.

62 Juda, op. cit. $12 \mathrm{ff}, 23$

63 Ibid.
} 
First, as pointed out, earlier, Australia has made enormous gains by proclaiming a Zone, whether it be fishing or economic, in accordance with the Convention. The sea area it now controls greatly outstrips its former area of authority (12 miles).

Secondly, Australia does not engage in distant water fishing so that its interests could not be jeopardized by the proclamation of such a Zone.

Thirdly, Australia only possesses minimal stocks in any event and this means that it is economically unfeasible for many fishing nations to finance operations in Australian waters. The few countries which do fish within these waters often fish for stocks which do not form part of the Australian fishing industry anyway - stocks such as squid, which the Japanese require. Therefore, the history of fishing agreements between Australia and foreign fishing nations has generally been amicable. The preponderance of the phrase 'joint venture' reflects this cooperation. There is, then, no need for Australia to extend its authority beyond that provided by a fishing Zone. The economic needs of the Australian community are not dependent upon the fishing industry, unlike a country like Fiji which relies on fishing for $8 \%$ of its export income. ${ }^{64}$

\section{CONCLUSIONS: STATUS OF THE E.E.Z. AND IMPLICATIONS FOR FOREIGN FISHING AND SECURITY IN THE PACIFIC}

The concept of the E.E.Z. is crucial to the conservation and management of the living resources of the ocean given that over three-quarters of the world's fishing stocks are included within E.E.Z.s.

Nowhere is this more apparent than in the Pacific region. There are very few enclaves between Zones. This factor alone led the Australian Ambassador to the U.S., Mr F. Rawdon Dalrymple, to comment that the map of the South Pacific had undergone a 'striking transformation . . . that was going to change . . . [the South Pacific's] political importance and its strategic importance'. ${ }^{65}$

Fishing is crucial to the industry of the South West Pacific, forming a significant part of the G.D.P. of many island economies. Additionally, other benefits accrue to the coastal state under the E.E.Z. proclamation, inlcuding research and marine environment control. ${ }^{66}$

The concept is now part of customary international law. The most significant element of the doctrine is that coastal states can exercise their discretionary control in determining whether or not to grant access to third parties who wish to fish within the E.E.Z. This has led to some writers claiming that there are dangers associated with it.

This paper has argued that while determination of access is entirely discretionary, there are no necessary dangers attached to this authority. Burkes' view is correct when he argues that the economic benefits to be gained from granting access will usually result in access being granted.$^{67}$ Most small coastal states do not possess the financial or technical capacity to harvest the allowable catch and

\footnotetext{
64 Fiji Today 1984-5 Department of Information Publication, Fiji, 1985, 21.

65 Australian Foreign Affairs Record, Vol. 56, Sept. 1985, 818.

66 Phillips, op. cit. 278.

67 Burke, op cit.
} 
are only too willing to accommodate the needs of foreign fishing powers. In the case of Australia, it is illustrated by a statement of Senator Grimes in the Parliament in October 1984. He said:

... in the absence of clear evidence that our marlin industry or resource is being significantly affected, the imposition of a total ban on the taking of marlin ... would undoubtedly bring a strong reaction from Japan, especially in view of our international obligations to permit foreign vessel access to those resources of our Zone which are excess to our harvesting capacity. ${ }^{68}$

Clearly the decision to refuse access will not be taken lightly.

It may be that there is another factor underlying the comments of writers such as O'Connell and Juda. This is the fear that 'unfriendly' countries may now get access to fishing resources which were traditionally refused to them. This economic access, it is thought, will provide some sort of leverage for these countries, notably the Soviet Union, to infiltrate other areas of the coastal states' domestic jurisdiction. The link between economic structural changes and security is perceived as a potential concern. Dr Stuart Harris, Secretary of the Department of Foreign Affairs, in an address to the National Defence University Symposium in February 1986 remarked that Pacific States

. . . are inevitably open to exploitation or infiltration from outside and concern has been expressed both about the U.S. industry's exploitation of tuna and the Soviet moves with Kiribati and other South Pacific nations. ${ }^{69}$

It appears from this statement that while Australian officials share some concerns about the ramifications of the E.E.Z. in the Pacific, they are taking a fairly evenhanded approach to the problem. They clearly believe that the problem does not lie with the doctrine itself, as spelled out in the Convention, but with its erroneous interpretation. The Australian Ambassador to the U.S., in a strongly worded speech to the Asian Society in 1985, urged the U.S. to reverse its policy of placing embargoes on countries which confiscate U.S. vessels fishing without licences for H.M.S. within their Zones. These actions threaten the island economies of small states and force them to negotiate with the Soviet Union. He continued,

if it is not satisfactorily resolved and resolved soon to the satisfaction of the South Pacific countries then I think it too will constitute in effect a gratuitous contribution towards making a hospitable climate for the Soviet Union, Libya, Cuba and others who would seek to radicalise and change the present political alignment of the region. ${ }^{70}$

This element has been further emphasized by the attitude of the Australian press.

Whatever the cause of the suspicion of the E.E.Z. doctrine it is now apparent that it forms part of international law and will serve as a mechanism to control the resources of the marine environment. It may also, as Belsky suggests, translate 'moral support' for the management of the eco-system into legal practice. At a time when the global environment is threatened by unregulated exploitation, the concept of the E.E.Z. is unparalleled in international law. The 'revolution' has already begun.

68 Australian Foreign Affairs Record Vol. 55, Oct. 1984, 1117. Author's italics.

69 Australian Foreign Affairs Record Vol. 57, Feb. 1986, 53.

70 Australian Foreign Affairs Record Vol. 56, Sept. 1985, 818. 


\section{Postscript}

On 1 April 1987, after exhaustive negotiations between the United States and the South Pacific Forum Fisheries Agency, an agreement was reached on fishing rights in the South Pacific region. Under the new arrangements the United States agreed to pay to the S.P.F.F.A. \$U.S. 10 million a year for 5 years for the right to seek licences within the region. A further $\$$ U.S.2 million is payable for the licences themselves and provision has also been made for the enforcement of the licences. 
This text is taken from Traversing the Divide: Honouring Deborah Cass's Contributions to Public and International Law, edited by Kim Rubenstein, published 2021 by ANU Press, The Australian National University,

Canberra, Australia.

doi.org/10.22459/TD.2021.10 